\title{
Are extended and continuous infusions of time dependent antibiotics used in the management of sepsis in england today?
}

\author{
JA Dunning ${ }^{1 *}, J C$ Roberts $^{2}$ \\ From ESICM LIVES 2015 \\ Berlin, Germany. 3-7 October 2015
}

\begin{abstract}
Introduction
Sepsis remains a leading cause of death in intensive care units. Administration of appropriate antibiotics within the first hour of diagnosis has been found to be the most effective intervention associated with a reduction in mortality [1]. Currently pharmacokinetic profiles of antibiotics are determined by phase II clinical trials that are undertaken by fit and well volunteers however many studies have shown that this data cannot be extrapolated accurately to the critically unwell [2]. Some have proposed that continuous and extended infusions of time dependent antibiotics maximise efficacy by increasing the time in which serum concentration is maintained above the minimum inhibitory concentration therefore improving clinical outcomes.
\end{abstract}

\section{Objectives}

This survey aimed to determine how many intensive care units in England currently use extended and continuous infusions of time dependent antibiotics in the treatment of sepsis.

\section{Methods}

One ICU in each acute trust in England was contacted via telephone in June 2014. A doctor working on the unit grade CT1 or above was then interviewed about antibiotic prescribing in sepsis.

\section{Results}

Of the 148 acute trusts with critical care facilities in mainland England 123 replied to the survey, 23 were unable to be contacted and 2 declined to respond; a

${ }^{1}$ Salford Royal Hospital, Undergraduate, Manchester, United Kingdom Full list of author information is available at the end of the article response rate of $83.1 \%$ was achieved. Of the trusts that responded antibiotic infusions were never used as a clinical strategy in the management of septic patients in 66 (54\%). Of the 57 (46\%) trusts that did consider using antibiotic infusions for the management of septic patients only $11(7 \%)$ used both continuous and extended infusions of antibiotics, 27 (18\%) used continuous infusions only and 19 (15\%) used extended infusions but not continuous infusions (Figure 1). Of the 57 trusts that used infusions of antibiotics; Vancomycin was administered by infusion in 48 (84\%) trusts and betalactams in $16(28 \%)$.

\section{Conclusions}

There remains disagreement regarding the clinical benefit of continuous and extended infusions of time dependent antibiotics in the management of septic patients in ICU. This is despite a large body of theoretical evidence based on pharmacokinetic studies. We suggest further, larger trials powered towards mortality are indicated for consensus to be achieved.

\footnotetext{
Authors' details

${ }^{1}$ Salford Royal Hospital, Undergraduate, Manchester, United Kingdom.

${ }^{2}$ Blackburn Royal Hospital, Intensive Care / Anaesthesia, Blackburn, United Kingdom.
}

Published: 1 October 2015

References

1. Díaz-Martín A, Martínez-González ML, Ferrer R, Ortiz-Leyba C, Piacentini E, Lopez-Pueyo MJ, Martín-Loeches I, Levy MM, Artigas A, GarnachoMontero J: Antibiotic prescription patterns in the empiric therapy of severe sepsis: combination of antimicrobials with different mechanisms of action reduces mortality. Critical Care 2012, 16:R223.

2. Blot S, Lipman J, Roberts DM, Roberts JA: The influence of acute kidney injury on antimicrobial dosing in critically ill patients: are dose (c) 2015 Dunning et al.; This is an Open Access article distributed under the terms of the Creative Commons Attribution License (http:// creativecommons.org/licenses/by/4.0), which permits unrestricted use, distribution, and reproduction in any medium, provided the original work is properly cited. 
reductions always necessary? Diagn Microbiol Infect Dis 2014, 79(1):77-84, May.

doi:10.1186/2197-425X-3-S1-A396

Cite this article as: Dunning and Roberts: Are extended and continuous

infusions of time dependent antibiotics used in the management of

sepsis in england today? Intensive Care Medicine Experimental 2015

3(Suppl 1):A396.

\section{Submit your manuscript to a SpringerOpen ${ }^{\mathcal{O}}$ journal and benefit from:}

- Convenient online submission

- Rigorous peer review

- Immediate publication on acceptance

- Open access: articles freely available online

- High visibility within the field

- Retaining the copyright to your article

Submit your next manuscript at $\gg$ springeropen.com 